\title{
Cyclosporin A Reverses Vincristine and Daunorubicin Resistance in Acute Lymphatic Leukemia In Vitro
}

\author{
Lewis M. Slater, Paula Sweet, Marie Stupecky, and Sudhir Gupta \\ Department of Medicine, College of Medicine, University of California, Irvine, California 92717
}

\begin{abstract}
The development of drug resistance by tumor cells is a major obstacle to the cure of human malignancy. Cyclosporin A (CsA) completely reverses primary resistance to vincristine and cross resistance to daunorubicin in a pleiotropic drug-resistant subline of human $\mathbf{T}$ cell acute lymphatic leukemia. This subline is over 50-fold resistant to vincristine and fivefold resistant to daunorubicin. CsA has little effect on vincristine or daunorubicin activity in drug-sensitive parental leukemia and corrects daunorubicin resistance without altering cellular daunorubicin accumulation.
\end{abstract}

\section{Introduction}

There has been recent interest in the ability of calcium channel blocking agents and calmodulin inhibitors to enhance the responses of drug-resistant tumor cells to vinca alkaloids and to anthracycline antibiotics (1-3). The mechanism of this effect relates in part to the ability of these agents to inhibit the enhanced active efflux of vinca alkaloids and anthracycline antibiotics by resistant cells, resulting in increased cellular drug retention $(1,4)$. Since the acquisition of equimolar concentrations of anthracyclines by anthracycline-resistant compared with anthracycline-sensitive tumor cells fails to restore equivalent cytotoxic drug effect to these cells, the mechanism by which calcium channel blocking agents and calmodulin inhibitors restore drug sensitivity must extend beyond drug retention $(5,6)$. We now report that cyclosporin $A(C s A)^{1}$ reverses vincristine (VCR) resistance in VCR-resistant human $\mathrm{T}$ cell acute lymphatic leukemia (ALL) and corrects the daunorubicin cross resistance of this leukemia subline. CsA has little effect on VCR or daunorubicin activity in drug-sensitive parental ALL, nor does it alter uptake or efflux of daunorubicin by daunorubicin-resistant ALL cells.

Address correspondence to Dr. Slater.

Received for publication 26 November 1985.

1. Abbreviations used in this paper: ALL, acute lymphatic leukemia; CsA, cyclosporin $A ; E_{50}, 50 \%$ effective dose; $L_{0}$, drug-sensitive tumor line; $\mathrm{L}_{100}$, VCR-resistant subline; VCR, vincristine.

J. Clin. Invest.

(c) The American Society for Clinical Investigation, Inc.

0021-9738/86/04/1405/04 \$1.00

Volume 77, April 1986, 1405-1408

\section{Methods}

A VCR-resistant subline of GM3639 cells (Human Genetic Mutant Cell Repository, Camden, NJ) was developed by continuous in vitro exposure of GM3639 $\left(\mathrm{L}_{0}\right)$ cells, initially to sublethal and then to progressively increased concentrations of vincristine as previously described (7). The drug-resistant subline $\left(\mathrm{L}_{100}\right)$, grown continuously in $100 \mathrm{nM}$ VCR, shows primary resistance to vincristine and cross resistance to daunorubicin and to VP-16 (7). VCR sensitivity of $L_{0}$ and $L_{100}$ cells is measured in a cytotoxicity assay, in which cell viability in increasing concentrations of VCR is compared with cell viability in the absence of VCR (7). Daunorubicin sensitivity of $L_{0}$ and $L_{100}$ cells is measured by the ability of daunorubicin to inhibit thymidine incorporation into DNA in these cell lines as previously described; this method correlates well with responses of daunorubicin-sensitive and daunorubicin-resistant Ehrlich ascites carcinoma in vivo (2). Uptake and efflux of $\left[{ }^{3} \mathrm{H}\right]$ daunorubicin by these leukemic cell lines is measured by previously described methods (8). CsA was kindly provided in powder form by Dr. David Winter, Sandoz, Inc., East Hanover, NJ.

\section{Results}

Fig. 1 compares the effects of increasing concentrations of CsA on VCR cytotoxicity in drug-sensitive $\mathrm{L}_{0}(A)$ and VCR-resistant $\mathrm{L}_{100}$ cells $(B)$ and Fig. 2 compares the effects of increasing concentrations of CsA on daunorubicin inhibition of DNA synthesis in these same cell lines. Table I presents the statistical evaluation of three or more such experiments. $\mathrm{L}_{100}$ cells are over 50 -fold resistant to VCR and are fivefold resistant to daunorubicin compared with $\mathrm{L}_{0}$ cells. The VCR concentration required for cytotoxicity of $50 \%$ of the cell population $\left(E D_{50}\right)$ assayed at $72 \mathrm{~h}$ for $\mathrm{L}_{0}$ cells is $11.9 \pm 2.4 \mathrm{nM}$ and for $\mathrm{L}_{100}$ cells, $701.7 \pm 91.7 \mathrm{nM}$. The concentration of daunorubicin required for $50 \%$ inhibition of thymidine incorporation into DNA for $\mathrm{L}_{0}$ cells is $1.6 \pm 0.7 \mu \mathrm{g} /$ $\mathrm{ml}$ and for $\mathrm{L}_{100}$ cells is $8.4 \pm 2.4 \mu \mathrm{g} / \mathrm{ml}$. The addition of $3.3,6.6$, and $13.2 \mu \mathrm{g} / \mathrm{ml} \mathrm{CsA}$ to cultures containing VCR or daunorubicin significantly reduces the respective $\mathrm{ED}_{50}$ values for $\mathrm{L}_{100}$ cells, the greatest concentration resulting in values characteristic of drugsensitive parental leukemia.

Fig. 3 is representative of three similar experiments which compare the transport of $\left[{ }^{3} \mathrm{H}\right]$ daunorubicin by $\mathrm{L}_{0}$ cells and $\mathrm{L}_{100}$ cells. After 30 min of drug uptake, $\left[{ }^{3} \mathrm{H}\right]$ daunorubicin efflux from $\mathrm{L}_{0}$ and $\mathrm{L}_{100}$ cells in the presence and absence of CsA is compared. It can be seen that daunorubicin uptake by daunorubicin-resistant cells is only slightly impaired compared with daunorubicinsensitive cells, and that the uptake of daunorubicin by daunorubicin-resistant cells is unaltered by CsA. Similar experiments carried out over $120 \mathrm{~min}$ also show only slightly greater 

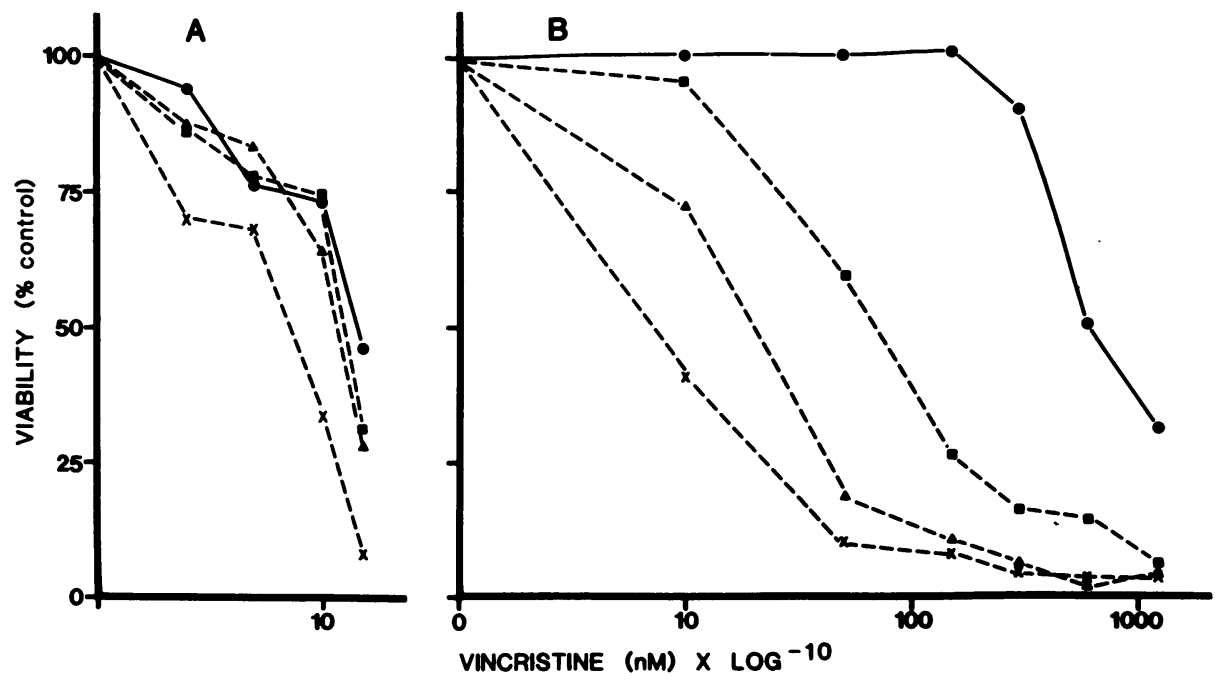

Figure 1. CsA effects on VCR $\mathrm{ED}_{50}$ values in drug-sensitive $(A)$ and drug-resistant ALL $(B)$. Cells are suspended in triplicate at $5 \times 10^{5}$ cells $/ \mathrm{ml}$ of culture medium in cluster culture plates with VCR (0-1,200 nM) and CsA in a 3-d cytotoxic assay. Cell viability in increasing concentrations of drug is compared with cell viability in the absence of drug with CsA in a final concentration of 0 $(-\bullet-), 3.3 \mu \mathrm{g} / \mathrm{ml}(---\bullet--), 6.6 \mu \mathrm{g} /$ $\mathrm{ml}(-\cdot-\Delta---)$, and $13.2 \mu \mathrm{g} / \mathrm{ml}(---\times---)$. After $3 \mathrm{~d}$, equivalent aliquots are taken from each triplicate culture and counted in duplicate with a hemocytometer, and cell viability is determined by means of trypan blue dye exclusion. In this system, the range between duplicate counts is $10 \%$. Each data point reflects the average of these counts divided by counts from control cultures without drug, and is expressed as percentage viability. The $\mathrm{ED}_{\mathbf{5 0}}$ is defined as that concentration of drug resulting in $50 \%$ viable cells at $3 \mathrm{~d}$ compared with cells maintained without VCR.

$\left[{ }^{3} \mathrm{H}\right]$ daunorubicin uptake by drug-sensitive vs. drug-resistant cells. The current series of experiments shows no effect of CsA on daunorubicin efflux from $\mathrm{L}_{100}$ cells. Fig. 3 demonstrates equivalent loss of $\left[{ }^{3} \mathrm{H}\right]$ daunorubicin from $\mathrm{L}_{100}$ cells in the presence and absence of $13.2 \mu \mathrm{g} / \mathrm{ml} \mathrm{CsA}$.

\section{Discussion}

Our experiments show that CsA completely reverses primary resistance to VCR and cross resistance to daunorubicin in drugresistant ALL. These effects are not limited to neoplastic human lymphoid cells since we have noted similar effects of CsA in daunorubicin-resistant Ehrlich ascites carcinoma in vitro and complete reversal of daunorubicin resistance by CsA in vivo (unpublished observations). In comparison to $\mathrm{L}_{100}$ cells, Ehrlich ascites carcinoma cells are resistant to daunorubicin because of prolonged direct exposure to daunorubicin in vivo (2). The daunorubicin-resistant Ehrlich ascites carcinoma subline is similar to the $L_{100}$ subline since it also shows only slightly impaired uptake of daunorubicin compared with daunorubicin-sensitive parental tumor (8). Our current experiments also show that CsA fails to effect daunorubicin uptake or efflux by $L_{100}$ cells, indicating that the restoration of daunorubicin responsiveness by CsA must depend on mechanisms independent of modified daunorubicin transport.

The CsA-restorative mechanism is unclear but may relate to calmodulin inhibition. It has recently been reported that human ALL cells have a 10-fold greater concentration of calmodulin than normal peripheral blood lymphocytes and that CsA is a potent inhibitor of $\mathrm{T}$ lymphocyte calmodulin $(9,10)$.
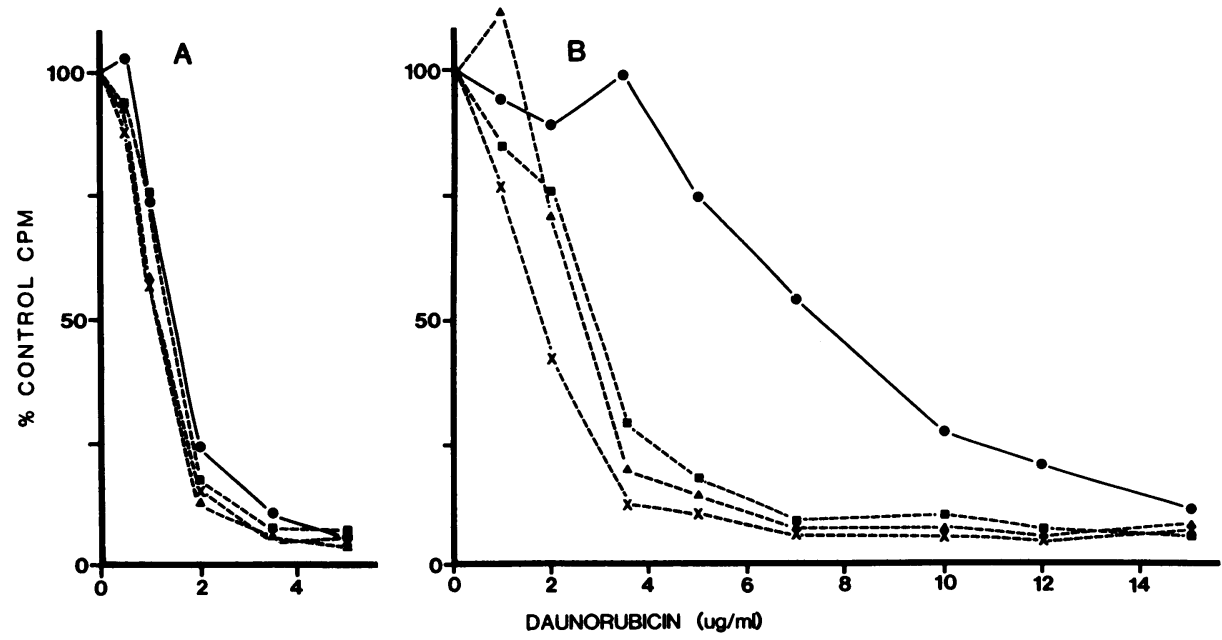

Figure 2. CsA effects on daunorubicin $\mathrm{ED}_{50}$ values in drug-sensitive $(A)$ and drug-resistant ALL $(B)$. Cells were counted on a hemocytometer using dye exclusion, washed, and resuspended in RPMI 1640 at a concentration of 1.6 $\times 10^{6} / \mathrm{ml}$. Cell aliquots of $1.6 \mathrm{ml}$ were incubated with $0.2 \mathrm{ml}$ daunorubicin $\mathrm{HCL}$ (final concentration $0-15 \mu \mathrm{g} / \mathrm{ml}$ ) for $1 \mathrm{~h}$ at $37^{\circ} \mathrm{C}$, washed twice, and resuspended in $1.8 \mathrm{ml} \mathrm{RPMI}$ and $0.2 \mathrm{ml}$ cyclosporin $\mathrm{A}$ at a final concentration of $0(-\bullet-), 3.3 \mu \mathrm{g} / \mathrm{ml}(---\bullet---), 6.6 \mu \mathrm{g} /$ $\mathrm{ml}(---\Delta---)$, and $13.2 \mu \mathrm{g} / \mathrm{ml}(---\times---)$. Triplicate $180-\mu l$ aliquots were placed into microtiter plates and incubated with $20 \mu \mathrm{l}\left[{ }^{3} \mathrm{H}\right]$ thymidine (specific activity $24 \mathrm{Ci} / \mathrm{mmol}$, final concentration 1 $\mu \mathrm{Ci} / \mathrm{ml}$ ) for $1 \mathrm{~h}$ at $37^{\circ} \mathrm{C}$ and $5 \% \mathrm{CO}_{2}$.

The filters were dried and counted in a PPO/POPOP/toluene liquid scintillation system. Values are plotted as percent inhibition of $\left[{ }^{3} \mathrm{H}\right]$ thymidine incorporation compared with control in the absence of daunorubicin. 
Table I. CsA Alteration of VCR and Daunorubicin $E D_{50}$ Values

\begin{tabular}{|c|c|c|c|c|c|}
\hline \multirow[b]{2}{*}{ Cell line } & \multirow[b]{2}{*}{ CsA } & \multicolumn{2}{|l|}{ VCR } & \multicolumn{2}{|c|}{ Daunorubicin } \\
\hline & & $\mathrm{ED}_{50} \pm \mathrm{SD}$ & $P$ & $\mathrm{ED}_{\mathrm{s0}} \pm \mathrm{SD}$ & $P$ \\
\hline & $\mu g / m l$ & $n M$ & & $\mu g / m l$ & \\
\hline (A) $\mathrm{L}_{0}$ & - & $11.9 \pm 2.4$ & - & $1.6 \pm 0.7$ & - \\
\hline (B) $\mathrm{L}_{100}$ & - & $701.7 \pm 91.7$ & $<0.01$ vs. $(A)$ & $8.4 \pm 2.4$ & $<0.01$ vs. $(A)$ \\
\hline (C) $\mathrm{L}_{100}$ & 3.3 & $183.0 \pm 87.7$ & $<0.05$ vs. $(B),>0.1$ vs. $(A)$ & $4.9 \pm 1.4$ & $>0.05$ vs. $(B),(A)$ \\
\hline (D) $\mathrm{L}_{100}$ & 6.6 & $43.3 \pm 29.2$ & $<0.02$ vs. $(B),>0.1$ vs. $(A)$ & $3.4 \pm 0.6$ & $<0.01$ vs. $(B),<0.02$ vs. $(A)$ \\
\hline (E) $\mathrm{L}_{100}$ & 13.2 & $13.8 \pm 10.6$ & $<0.01$ vs. $(B),>0.01$ vs. $(A)$ & $2.3 \pm 0.5$ & $<0.01$ vs. $(B),>0.1$ vs. $(A)$ \\
\hline
\end{tabular}

However, in the cell lines studied, anthracycline and velbansensitive and -resistant ALL cells have the same calmodulin content, an observation which fails to explain the selective action of CsA in daunorubicin-resistant ALL $(11,12)$. The studies of LeGrue et al. (13) raise the possibility that CsA might function in the plasma membrane in a manner similar to that of lipid soluble anesthetics by increasing lipid fluidity and uncoupling electrochemical action potentials. Enhanced drug retention alone cannot account for the effects of calcium channel blocking drugs and calmodulin inhibitors on vinca alkaloid and anthracycline

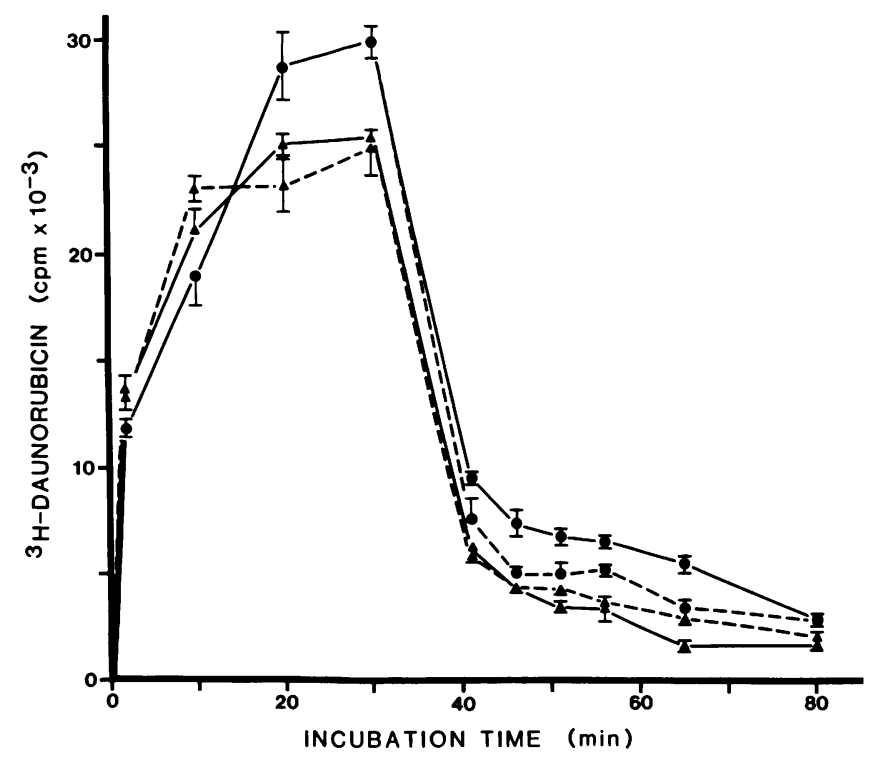

Figure 3. $\left[{ }^{3} \mathrm{H}\right]$ daunorubicin uptake and efflux of sensitive $(\bullet)$ and re-

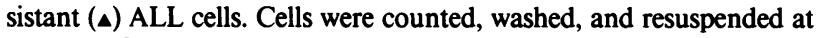
$22.5 \times 10^{5}$ cells/ml RPMI 1640 without $(-)$ or with $(---) 13.2$ $\mu \mathrm{g} / \mathrm{ml}$ cyclosporin $\mathrm{A}$ and $\left[{ }^{3} \mathrm{H}\right]$ daunorubicin (specific activity $1.5-2.5$ $\mathrm{Ci} / \mathrm{mmol}$, final concentration $5 \mu \mathrm{g} / \mathrm{ml}$ daunorubicin and $5 \mu \mathrm{Ci} / \mathrm{ml}$ ). Immediately and at designated time points, triplicate aliquots of 200 $\mu l\left(\right.$ at $\left.37^{\circ} \mathrm{C}\right)$ were placed in microtiter plate wells and harvested onto glass fiber filters using a titertek multiple sample harvester. The filters were dried and counted in a PPO/POPOP/toluene liquid scintillation system. Efflux at $37^{\circ} \mathrm{C}$ was measured after $30 \mathrm{~min}$ of drug uptake. Aliquots were removed from the uptake suspension, centrifuged, washed, and resuspended in same volume of RPMI 1640. Triplicate 200- $\mu$ I samples were taken immediately and at indicated time points and processed as above. antibiotics in pleiotropic drug-resistant cells $(5,6)$. It has therefore been suggested that these agents, and it now appears that CsA, may promote favorable chemotherapeutic drug interactions at the membrane level or enhance intracellular drug binding $(5,12)$.

The clinical use of calcium channel blocking agents has been limited by high concentration requirements (14). However, since large doses of CsA have been administered to man with reasonable safety, and concentrations approaching those that are required for restoration of VCR and daunorubicin responses in ALL in vitro are achievable in vivo, CsA may prove to be a useful agent in the treatment of vinca alkaloid and anthracycline antibiotic-resistant neoplasia (15-17).

\section{Acknowledgment}

We thank Dr. Harry Wallerstein for his continuous encouragement and the Marcia Slater Society for Research in Leukemia for financial support.

\section{References}

1. Tsuruo, T., H. Iida, S. Tsukagoshi, and Y. Sakurai. 1981. Overcoming of vincristine resistance in P388 leukemia in vivo and in vitro through enhanced cytotoxicity of vincristine and vinblastine by verapamil. Cancer Res. 41:1967-1972.

2. Slater, L. M., S. L. Murray, M. W. Wetzel, R. M. Wisdom, and E. M. DuVall. 1982. Verapamil restoration of daunorubicin responsiveness in daunorubicin-resistant Ehrlich ascites carcinoma. J. Clin. Invest. 70:1131-1134.

3. Tsuruo, T., H. Iida, M. Yamashiro, S. Tsukagoshi, and Y. Sakurai. 1982. Enhancement of vincristine- and adriamycin-induced cytotoxicity by verapamil in P388 leukemia and its sublines resistant to vincristine and adriamycin. Biochem. Pharmacol. 31:3138-3140.

4. Tsuruo, T., H. Iida, S. Tsukagoshi, and Y. Sakurai. 1982. Increased accumulation of vincristine and adriamycin in drug-resistant P388 tumor cells following incubation with calcium antagonists and calmodulin inhibitors. Cancer Res. 42:4730-4733.

5. Kessel, D., and C. Wilberding. 1985. Anthracycline resistance in P388 murine leukemia and its circumvention by calcium antagonists. Cancer Res. 45:1687-1691.

6. Sikic, B. I., B. B. Etiz, W. G. Harker, R. L. Anderson, and G. M. Hahn. 1985. Mechanisms of multidrug (pleiotropic) resistance in the human sarcoma cell line MES-SA. Proc. Am. Assoc. Cancer Res. 26: 1346a. (Abstr.)

7. Slater, L. M., S. L. Murray, M. W. Wetzel, P. Sweet, and M. Stupecky. 1986. Verapamil potentiation of VP-16-213 in acute lymphatic 
leukemia and reversal of pleiotropic drug resistance. Cancer Chemother. Pharmacol. 16:50-54.

8. Murray, S. L., E. M. DuVall, and L. M. Slater. 1984. Calcium modifies the accumulation and retention of daunorubicin by Ehrlich ascites carcinoma. Cancer Chemother. Pharmacol. 13:69-70.

9. Takemoto, D., and C. Jilka. 1983. Increased content of calmodulin in human leukemia cells. Leuk. Res. 7:97-100.

10. Colombani, P. M., A. Robb, and A. D. Hess. 1985. Cyclosporin A binding to calmodulin: a possible site of action on $\mathrm{T}$ lymphocytes. Science (Wash. DC). 228:337-339.

11. Nair, S., T. S. A. Samy, and A. Krishan. 1985. Calcium, calmodulin and protein content of adriamycin resistant and sensitive P388 cells. Proc. Am. Assoc. Cancer Res. 26:1365a. (Abstr.)

12. Beck, W. T. 1983. Vinca alkaloid-resistant phenotype in cultured human leukemic lymphoblasts. Cancer Treat. Rep. 67:875-882.

13. LeGrue, S. J., A. W. Friedman, and B. D. Kahan. 1983. Binding of cyclosporine by human lymphocytes and phospholipid vesicles. $J$. Immunol. 131:712-718.

14. Kessel, D., and C. Wilberding. 1985. Promotion of daunorubicin uptake and toxicity by the calcium antagonist tiapamil and its analogs. Cancer Treat. Rep. 69:673-676.

15. Kennedy, M. S., H. J. Deeg, R. Storb, K. Doney, K. M. Sullivan, R. P. Witherspoon, F. R. Applebaum, P. Stewart, J. Sanders, C. D. Buckner, P. Martin, P. Weiden, and E. D. Thomas. 1985. Treatment of acute graft-versus-host disease after allogeneic marrow transplantation. Am. J. Med. 78:978-9983.

16. Griffith, B. P., R. L. Hardesty, A. Trento, A. Lee, and H. T. Bahnson. 1984. Targeted blood levels of cyclosporine for cardiac transplantation. J. Thorac. Cardiovasc. Surg. 88:952-957.

17. Atkinson, K., K. Britton, and J. Biggs. 1984. Distribution and concentration of cyclosporin in human blood. J. Clin. Pathol. (Lond.). 37:1167-1171. 